\title{
$\mathbb{A}$ Economics Bulletin
}

\section{Volume 39, Issue 2}

\section{Gender Inequality in Education and per capita GDP: the case of CEMAC Countries}

\author{
Giscard Assoumou-ella \\ Omar Bongo University (CIREGED) and LEAD, University of Toulon (France)
}

\begin{abstract}
The global objective of the paper is to analyze the direct and indirect effects of gender inequality in education on GDP per capita of the Central African Economic and Monetary Community (CEMAC) countries over the period from 1980 to 2014. Using an IV estimate and the GMM system estimator from Blundel and Bond (1998), the results show that an increase of gender equality index at primary-secondary and tertiary levels increases GDP per capita. Like the estimates using the gender equality index, a decrease of gender inequalities in education completion according to age groups has a beneficial effect on GDP per capita of the sample countries. As a result, CEMAC countries need to implement policies that reduce gender inequalities in education for sustainable economic growth. Also, an indirect negative impact of political instability, oil shocks and adolescent fertility on GDP is established.
\end{abstract}

Citation: Giscard Assoumou-ella, (2019) "Gender Inequality in Education and per capita GDP: the case ofCEMAC Countries", Economics Bulletin, Volume 39, Issue 2, pages 1154-1162

Contact: Giscard Assoumou-ella - g.assoumouella@gmail.com.

Submitted: February 07, 2019. Published: May 15, 2019. 


\section{Introduction}

Maintaining women outside of education makes the world less fair and less secure, and reduces aggregate well-being (Sen, 1999). For this, education for all is one of the important points of the Millennium Development Goals. The Central African Economic and Monetary Community countries (CEMAC) ${ }^{1}$ committed to achieving this educational goal. However, gender inequality in education remains high in this region (see table 1). In this context, this article aims to evaluate the effect of gender inequality in education on GDP per capita in these countries.

Several reasons can justify why gender inequality may impede GDP per capita in CEMAC. In fact, the growth of CEMAC countries is highly natural resource dependent. Five out of six countries in the region are oil exporters. This resource dependence has implications for the labor market, including the need for different types of skill sets, and the sustainability of growth. Higher export and output diversification would help these countries to gain resilience against shocks. In this context, an educated workforce, including educated women, will be critical for having a sustainable growth.

We use two approaches for measuring gender inequality. Firstly, gender inequality is measured in terms of education completion based on population within specific age brackets. Secondly, it is measured in terms of Gender Parity Index (GPI). United Nations Educational, Scientific and Cultural Organization (UNESCO) uses this indicator to evaluate the level of gender inequalities in education between men and women for primary, secondary and tertiary levels enrollment. A GPI of less than 1 indicates that there are proportionally fewer females than males in education system, and conversely. Perfect equality in terms of enrolment rates is represented by a GPI equal to 1 .

Thus, this paper is a contribution to the literature on the effect of gender inequality in education on GDP in Africa. On the theoretical level, based on Solow (1957) model, the analysis shows that output with educational gender equality is higher than output with educational gender inequality. This theoretical result is empirically verified. Indeed, the results obtained show that an increase of gender equality index at the primary-secondary and tertiary levels increases GDP per capita. Like the estimates using the GPI, a decrease of gender inequalities in education completion according to age groups has a beneficial effect on the GDP of the CEMAC countries. In addition, the study establishes an indirect negative impact of political instability, oil shocks and adolescent fertility on GDP per capita. Finally, the study shows that the decreases of gender inequalities in the labor market, FDI and public spending have a beneficial indirect effect on GDP (results available on request).

The document is organized as follows: Section 2 presents the selected literature review. Section 3 presents the stylized facts. Sections 4 and 5 present the theoretical model of reference, the econometric modeling and the results. Finally, section 6 concludes.

\footnotetext{
${ }^{1}$ CEMAC: Gabon, Cameroon, Central African Republic, Chad, Republic of the Congo and Equatorial Guinea. For data availability problem, Equatorial Guinea is not taking into account in analysis.
} 


\section{Selected Literature Review}

The objective in this section is to present the studies on the effect of educational gender inequality on economic growth. Thus, Lagerlöf (1999, 2003) analyses the links between gender inequality in education, fertility and economic growth. Using an overlapping generation models, the author shows that self-perpetuation of gender inequality leads to high fertility and low economic growth. The ultimate consequence is the "trap of poverty"; justifying government intervention. The results of Agénor et al. (2010; 2015) and Agénor and Canuto (2015) go in the same direction. Using an overlapping generation models of endogenous growth, the authors show that more gender equality in education improves human capacities in the next generation. Women's greater educational equality improves their bargaining power and leads to greater resources invested in children. That is the nexus for the intergenerational transmission of productivity effects.

The existence of the new data bases to quantify the inequalities has enabled the development of several recent empirical studies, particularly the econometrics of panel data to analyze the impact of gender inequality on economic growth (Klasen and Lamanna, 2009). Brummet (2008) wants to solve it by using the ratios of gender inequality, and not the gross enrollment rates. By controlling the multicollinearity problem, a high level of gender inequality in education has a negative effect on economic growth. As well, this result is robust not only with introduction of other variables, but also by changing the specification of gender inequality. Contrary to Brummet (2008), Klasen and Lamanna (2009) studied the combined effect of gender inequality in education and labor market on economic growth. They find that increasing gender inequality in education has a negative effect on economic growth. Using panel data over the study period from 1960 to 2000, they compare the results from different regions and found that the combined cost of gender inequality in education and labor market would be 0.9 and 1.6 to Middle East and North Africa; a difference of cost of 0.9 and 1.6 compared to East Asia situation.

Concerning African countries, using Arellano-Bond dynamic panel method for the 1974 to 2001 period and the ratio of 15-24-year-old literate females to males as an educational gender gap indicator, Baliamoune-Lutz and McGillivray (2009) argue that gender inequalities in literacy have a negative effect on growth in 31 sub-Saharan African countries and in 10 Arab countries. Seguino and Were (2013) analyze the theoretical and empirical macro-growth effects of gender inequality in sub-Saharan Africa. For them, public investment in education and a central banking with a monetary policy that sustains employment are two policies that can promote gender equality and growth in Sub-Saharan Africa. In the same perspective, Licumba et al. (2015) show a positive effect of gender equality on economic growth in five Southern African countries between 1970 and 2010.

\section{Stylized Facts}

Table 1: Descriptive analysis of the data

\begin{tabular}{c|c|c|c|c|c} 
Variable & Obs & Mean & Std. Dev. & Min & Max \\
\hline$Y$ & 175 & 1831.093 & $\mathbf{2 4 1 9 . 9 7 5}$ & $\mathbf{1 6 6 . 0 0 8}$ & $\mathbf{0 . 0 6 1 5}$ \\
\hline schoolt & 175 & $\mathbf{0 . 3 5 5 5 8 2 1}$ & $\mathbf{0 . 2 2 4 0 3 5 6}$ & $\mathbf{0 . 8 1 2 3 8}$ \\
\hline schoolps & 175 & $\mathbf{0 . 7 6 0 7 2 0 7}$ & $\mathbf{0 . 1 8 3 4 4 4 3}$ & $\mathbf{0 . 3 4 8 8 9}$
\end{tabular}




\begin{tabular}{c|c|c|c|c|c} 
comp_prim_15-24 & $\mathbf{1 7 5}$ & $\mathbf{0 . 4 8 5 5 1 2 7}$ & $\mathbf{0 . 2 6 1 5 1 6 6}$ & $\mathbf{0 . 0 5 8 6 6 3 2}$ & $\mathbf{0 . 8 8 6 1 1 4 6}$ \\
\hline comp_lowsec_15-24 & $\mathbf{1 7 5}$ & $\mathbf{0 . 1 4 7 7 2 9 2}$ & $\mathbf{0 . 0 9 8 5 9 1 3}$ & $\mathbf{0 . 0 1 4 1 1 3 1}$ \\
\hline comp_upsec_20-29 & $\mathbf{1 7 5}$ & $\mathbf{0 . 0 5 8 5 9 1 5}$ & $\mathbf{0 . 0 4 7 2 7 8 2}$ & $\mathbf{0 . 0 0 2 9 8 1 5}$ & $\mathbf{0 . 4 0 3 6 8 7 3}$ \\
\hline comp_higher_25-29_2years & $\mathbf{1 7 5}$ & $\mathbf{0 . 0 3 3 5 6 1 6}$ & $\mathbf{0 . 0 3 1 4 6 2 6}$ & $\mathbf{0 . 0 0 1 0 5 4 8}$ \\
\hline comp_higher_25-29_4years & $\mathbf{1 7 5}$ & $\mathbf{0 . 0 1 1 4 9 5}$ & $\mathbf{0 . 0 1 8 4 0 4 3}$ & $\mathbf{0 . 0 0 0 3 5 1 6}$ & $\mathbf{0 . 1 5 6 9 3 1 8}$ \\
\hline comp_higher_30-34_4years & $\mathbf{1 7 5}$ & $\mathbf{0 . 0 1 3 3 4 8 4}$ & $\mathbf{0 . 0 2 1 3 8 2 7}$ & $\mathbf{0 . 0 0 1 1 3 9 2}$ \\
\hline Female population & $\mathbf{1 7 5}$ & $\mathbf{5 0 . 3 8 8 6 8}$ & $\mathbf{0 . 4 2 1 4 0 9 4}$ & $\mathbf{4 9 . 9 4 8 8 6}$ & $\mathbf{0 . 1 2 2 0 6 3 8}$ \\
\hline Female population (0-14) & $\mathbf{1 7 5}$ & $\mathbf{4 9 . 7 6 1 7 5}$ & $\mathbf{0 . 2 3 1 4 2 4 9}$ & $\mathbf{4 9 . 9 9 5 9 9}$ & $\mathbf{5 0 . 5 5 8 4 3}$ \\
\hline Female population (15-65) & $\mathbf{1 7 5}$ & $\mathbf{5 0 . 8 0 0 0 8}$ & $\mathbf{1 . 2 6 4 4 9 5}$ & $\mathbf{5 1 9 . 8 4 2 8}$ & \\
Source: World Development Indicators, Gender Statistics, UNESCO (World Inequality Database on Education) and auteur
\end{tabular}

According to table 1, the average GDP per capita of the CEMAC is $\$ 1831.093$. The minimum and the maximum values are 166.008 and 11530.15 . The average values of the gender equality indices in primary-secondary (schoolps) and tertiary (schoolt) are respectively 0.76 and 0.355 . Thus, on average, 76 girls per 100 boys are enrolled in primary and secondary schools and 35 girls per 100 boys in tertiary education in CEMAC. Thus, the higher is the level of study, the more inequalities increase. In addition, there are strong inequalities between men and women in terms of education completion. In fact, in the 15-24 age group of population who have completed primary education (comp_prim_15-24), there are only 48\% of women. In the 15-24 age group of population who have completed high school (comp_lowsec_15-24), there are only 14\% of women. In the 25-29 age group of population with two years of university education (comp_higher_25-29_2years), there are only 3\% of women. Only $1 \%$ of women have four years of university education completion in the 25-29 age group of population (comp_higher_25-29_4years). In the 30-34 age group of population with four years of university education completion (comp_higher_30-34_4years), there are only $1 \%$ of women.

\section{Theoretical Framework}

The analysis is based on GDP of 5 CEMAC countries. The theoretical framework is Solow (1957) model. As IMF (2015), we assume a Cobb-Douglas production function. Thus, the output can be written as:

$Y_{i}=A_{i} K_{i}^{\alpha} H_{i}^{1-\alpha}$

Where $i$ represents the country, $K_{i}$ and $H_{i}$ are respectively physical and human capital stocks in country $i . A_{i}, \alpha$ and $1-\alpha$ are respectively total factor productivity in country $i$, productivity of physical capital and productivity of human capital. Knowing that $H=\gamma P_{M}+$ $\delta P_{F}$, with $P_{M}, P_{F}, \gamma$ and $\delta$ are respectively male population, female population, portion of educated male in $P_{M}$ and portion of educated female in $P_{F}$, with $\gamma$ and $\delta \in[0 ; 1]$, we can rewrite equation (1) as :

$Y_{i}=A_{i} K_{i}^{\alpha}\left(\gamma P_{M}+\delta P_{F}\right)_{i}^{1-\alpha}$

According to table 1 , female population $(\mathrm{fm})$ represents in average $50 \%$ of total CEMAC population in the study period. Thus, we rely on this empirical observation for assuming that $P_{M} \cong P_{F}$. The output becomes:

$Y_{i}=A_{i} K_{i}^{\alpha}\left\{(\gamma+\delta) P_{M}\right\}_{i}^{1-\alpha}$ 
Based on the preceding assumption, perfect educational gender equality implies $\gamma=\delta$. In this context, we have:

$Y_{i}=A_{i} K_{i}^{\alpha}\left(2 \gamma P_{M}\right)_{i}^{1-\alpha}$

Equation (4) has two implications. Firstly, the effect of educational gender equality on output in CEMAC depends on the value of $\gamma$. More $\gamma$ is close to 1 ; more educational gender equality improves GDP. In other words, a high level of human capital in a country improves the beneficial effect of gender equality in education on GDP. Secondly, output with gender educational equality is higher than output with gender educational inequality: (1)': $A_{i} K_{i}^{\alpha}\left(2 \gamma P_{M}\right)_{i}^{1-\alpha}>(2)^{\prime}: A_{i} K_{i}^{\alpha}\left\{(\gamma+\delta) P_{M}\right\}_{i}^{1-\alpha}>(3)^{\prime}: A_{i} K_{i}^{\alpha}\left(\gamma P_{M}\right)_{i}^{1-\alpha}$. (1)', $(2)^{\prime}$ and (3)' are respectively output with perfect educational gender equality $(\gamma=\delta)$, output with educational gender inequality $(\gamma>\delta)$ and output with total educational gender inequality $(\delta=0)$.

\section{Empirical estimation}

\subsection{Choice of the models}

In the literature, the problem of endogeneity between production and education, as well as the omitted variables problem are solved by using instrumental variable estimation like Dollar and Gatti (1999) in static models. In dynamics, the most commonly used estimation method is the generalized moments (GMM) like Baliamoune-Lutz and McGillivray (2009), Qureshi et al. (2011). Roodman (2009) argues that many instruments can weaken the Hansen test. Thus, to correct endogeneity and omitted variables problem, we used the following instrumental variables for the IV estimates: FDI and the gender gap in the labor market. We perform the Nakamura and Nakamura (1981) endogeneity test and the Sargan over-identification test to verify the validity of the instruments. The period studied goes from 1980 to 2014. Data come from World Bank (World Development Indicators and Gender Statistics) and UNESCO (World Inequality Database on Education). We used the extrapolation and the nearest neighborhood methods to fill in the missing data. For the dynamic panel, it is estimated using the GMM system estimator of Blundel and Bond (1998) which combines the equations in first difference with the equations in level. In addition, we use the Sargan tests for the validity of the instruments and we check the absence of serial correlation of the residues. The estimated system is as follows:

$\left\{\begin{array}{c}\Delta Y_{i, t}=\beta \Delta Y_{i, t-1}+\delta \Delta \text { schoolt }_{i, t-1}+\theta \Delta X_{i, t}+\Delta v_{t}+\Delta \varepsilon_{i, t} \\ Y_{i, t}=\beta Y_{i, t-1}+\delta \text { schoot }_{i, t-1}+\theta X_{i, t}+v_{t}+\varepsilon_{i, t}\end{array}\right.$

Y represents GDP per capita (Hill and King, 1995), $\Delta$ the first difference, schoolt the index of gender equality in education (Hill and King, 1995; Brummet, 2008). Thus, the explanatory variables are composed by the gender equality indices in primary-secondary (schoolps), tertiary (schoolt) education and gender inequality in education completion based on population within specific age brackets (comp_prim_15-24, comp_lowsec_15-24, comp_upsec_20-29, comp_higher_25-29_2years, comp_higher_25-29_4years and comp_higher_30-34_4years). $\mathrm{X}$ is the matrix of control variables, $v_{t}$ the country-specific 
effects not observed and $\varepsilon_{i, t}$ the specific errors observed, $t$ the time and $i$ the country index. The control variables are: infantile mortality (mort) (Kalemli-Ozcan, 2002; Lehmijoki and Palokangas, 2011), the interaction between the terms of trade and trade openness (tot ${ }^{*}$ ouv) (Eicher et al. 2008), private investment (inv) (Bint-e-Ajaz and Ellahi, 2012, Yovo, 2017), trade variables (exports $(x)$ and imports $(m)$ ) and the 1994 devaluation $(d e v)$ (Shahzad and Afzal, 2013; Osundina and Osundina, 2014).

\subsection{Interpretation of the results}

Only the tables that contain the results of the estimates of the direct effect are presented. Regarding tables which contain the result of the indirect effects, they are available on request. They are not included in the text in order to respect the number of pages required by the journal.

\subsubsection{Effect of gender equality index in education on GDP per capita}

Table 2: Direct effect of gender equality index in education on GDP per capita in static and dynamic estimations

\begin{tabular}{|c|c|c|c|c|c|}
\hline \multicolumn{3}{|c|}{ Static Results (IV estimate) } & \multicolumn{3}{|c|}{ Dynamic Results (GMM system estimator) } \\
\hline Dependent variables & $\begin{array}{c}\text { (6) } \\
\text { GDP per capita }\end{array}$ & $\begin{array}{l}\text { (7) } \\
\text { GDP per capita }\end{array}$ & Dependent variables & $\begin{array}{c}\text { (8) } \\
\text { GDP per capita }\end{array}$ & $\begin{array}{c}\text { (9) } \\
\text { GDP per capita }\end{array}$ \\
\hline schoolt & $\begin{array}{c}1.648^{* * *} \\
(0.371)\end{array}$ & --- & dgp per capita $(-1)$ & $\begin{array}{c}0.759^{* * *} \\
(0.032)\end{array}$ & $\begin{array}{c}0.752^{* * *} \\
(0.036)\end{array}$ \\
\hline schoolps & --- & $\begin{array}{l}1.128^{* * * *} \\
(0.505)\end{array}$ & schoolt & $\begin{array}{l}-0.184 \\
(0.177)\end{array}$ & --- \\
\hline mortality & $\begin{array}{c}-0.027^{* * * *} \\
(0.001)\end{array}$ & $\begin{array}{c}-0.024^{* * *} \\
(0.004)\end{array}$ & schoolt $(-1)$ & $\begin{array}{c}-0.32 \\
(0.217)\end{array}$ & --- \\
\hline lot $^{*}$ ouv & $\begin{array}{l}0.006^{* * *} \\
(0.001)\end{array}$ & $\begin{array}{l}0.004^{* * * *} \\
(0.000)\end{array}$ & schoolt $(-2)$ & $\begin{array}{l}0.358^{* *} \\
(0.185)\end{array}$ & -- \\
\hline inv & $\begin{array}{l}2.77^{* * * *} \\
(0.000)\end{array}$ & $\begin{array}{l}4.33^{* * *} \\
(0.000)\end{array}$ & schoolps & --- & $\begin{array}{c}0.188^{* * *} \\
(0.079)\end{array}$ \\
\hline$x$ & $\begin{array}{l}8.13^{* * * *} \\
(0.000)\end{array}$ & $\begin{array}{l}1.14^{* * *} \\
(0.000)\end{array}$ & Schoolps $(-1)$ & --- & $\begin{array}{l}0.533^{*} \\
(0.323)\end{array}$ \\
\hline$m$ & $\begin{array}{l}-3.85^{* * * *} \\
(0.000)\end{array}$ & $\begin{array}{l}-4.12^{* * * *} \\
(0.000)\end{array}$ & mortality & $\begin{array}{c}-0.004^{* * *} \\
(0.001)\end{array}$ & $\begin{array}{l}-0.001 \\
(0.002)\end{array}$ \\
\hline dev & $\begin{array}{l}-0.161 \\
(0.151)\end{array}$ & $\begin{array}{l}-0.165 \\
(0.157)\end{array}$ & lot $^{*}$ ouv & $\begin{array}{c}0.001 \\
(0.000)\end{array}$ & $\begin{array}{c}0.001^{* * *} \\
(0.000)\end{array}$ \\
\hline cst & $\begin{array}{c}8.141^{* * * *} \\
(0.279)\end{array}$ & $\begin{array}{c}7.544^{* * *} \\
(0.738)\end{array}$ & inv & $\begin{array}{l}-1.36 \\
(0.000)\end{array}$ & $\begin{array}{c}1.07 \\
(0.000)\end{array}$ \\
\hline Adjusted R2 & 0.91 & 0.91 & $x$ & $\begin{array}{l}4.24^{* * *} \\
(0.000)\end{array}$ & $\begin{array}{l}4.45^{* * * *} \\
(1.14) \\
-\end{array}$ \\
\hline Obs. & 175 & 175 & $m$ & $\begin{array}{c}-9.76 \\
(0.000)\end{array}$ & $\begin{array}{l}-3.45^{* *} \\
(1.77)\end{array}$ \\
\hline & & & $d e v$ & $\begin{array}{c}-0.285^{* * * *} \\
(0.05)\end{array}$ & $\begin{array}{c}-0.256^{* * * *} \\
(0.048)\end{array}$ \\
\hline & & & cst & $\begin{array}{c}2.013^{* * * *} \\
(0.309)\end{array}$ & $\begin{array}{c}1.148^{* * *} \\
(0.396)\end{array}$ \\
\hline & & & Obs. & 165 & 170 \\
\hline
\end{tabular}

Estimates are made in static and dynamic. According to the results in static ((6) and (7)), an increase of gender equality index at primary-secondary level of $100 \%$ increases the GDP per capita by $112.8 \%$. While an increase of gender equality index in the tertiary of $100 \%$ increases GDP per capita by $164.8 \%$. In dynamics ((8) and (9)), an increase of gender equality index in the primary-secondary level of $100 \%$ in the year $t-1$ and the year $t$ increases GDP per capita by 53.3 and $18.8 \%$ respectively. While an increase at the tertiary level of $100 \%$ in year t-2 increases GDP per capita by $35.85 \%$. The other years are not significant. Therefore, the empirical results go in the same direction as the theoretical result. A decrease of gender inequalities in education increases the GDP of the CEMAC countries. Regarding the indirect effects (results available on request), the interaction between political instability and gender equality index in education has a negative effect on the GDP per capita. The interaction 
between public expenditure and the gender equality index in education has a positive and significant effect on GDP per capita in both static and dynamic estimations. The interaction between the gender equality index in education and the ratio between the participation rate of women and men has a positive and significant effect on GDP per capita in static and dynamic estimations. The interaction between the gender equality index in education and foreign direct investment flows has a positive and significant effect on GDP per capita in both static and dynamic estimations. The interaction between the oil shock, the gender equality index and the change in public spending has a significant and negative effect on GDP per capita in dynamic estimation. Finally, the interaction between adolescent fertility rate and the gender equality index in education has a negative and significant impact on GDP per capita both in static and dynamic estimations.

\subsubsection{Gender inequality in education completion based on population within specific age brackets and GDP per capita}

Table 3: Static effect on GDP per capita of gender inequality in education completion based on population within specific age brackets (IV estimate)

\begin{tabular}{|c|c|c|c|c|c|c|}
\hline Dependent variables & $\begin{array}{l}\text { (10) } \\
\text { GDP per capita }\end{array}$ & $\begin{array}{l}\text { (11) } \\
\text { GDP per capita }\end{array}$ & $\begin{array}{l}\text { (12) } \\
\text { GDP per capita }\end{array}$ & $\begin{array}{l}\text { (13) } \\
\text { GDP per capita }\end{array}$ & $\begin{array}{l}\text { (14) } \\
\text { GDP per capita }\end{array}$ & $\begin{array}{l}\text { (15) } \\
\text { GDP per capita }\end{array}$ \\
\hline comp_prim_15-24 & $\begin{array}{c}1.793^{* * * *} \\
(0.764)\end{array}$ & --- & -- & --- & -- & -- \\
\hline comp_lowsec_15-24 & ---- & $\begin{array}{c}1.684^{* * *} \\
(0.61)\end{array}$ & -"- & --- & - & - \\
\hline comp_upsec_20-29 & --- & -- & $\begin{array}{l}1.375^{*} \\
(0.736)\end{array}$ & --- & 等- & - --- \\
\hline comp_higher_25-29_2years & --- & --- & - & $\begin{array}{c}1.128^{* * * *} \\
(0.511)\end{array}$ & 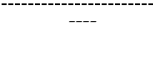 & - \\
\hline comp_higher_25-29_4years & --- & --- & --- & --- & $\begin{array}{c}0.785^{* * * *} \\
(0.279)\end{array}$ & - \\
\hline comp_higher_30-34_4years & - & - & - & --- & -- & $\begin{array}{c}0.932^{* * * *} \\
(0.272)\end{array}$ \\
\hline mortality & $\begin{array}{c}0.023 \\
(0.023)\end{array}$ & $\begin{array}{l}0.025 \\
(0.02)\end{array}$ & $\begin{array}{c}.023 \\
(0.029) \\
\end{array}$ & $\begin{array}{c}0.016 \\
(0.022) \\
\end{array}$ & $\begin{array}{l}-0.001 \\
(0.011)\end{array}$ & $\begin{array}{l}-0.006 \\
(0.007)\end{array}$ \\
\hline lot ${ }^{*}$ ouv & $\begin{array}{c}0.003^{* * *} \\
(0.001)\end{array}$ & $\begin{array}{c}0.003^{* * *} \\
(0.001)\end{array}$ & $\begin{array}{l}-0.001 \\
(0.002)\end{array}$ & $\begin{array}{c}0.002 \\
(0.001)\end{array}$ & $\begin{array}{c}0.004^{* * * *} \\
(0.001)\end{array}$ & $\begin{array}{c}0.003^{* * *} \\
(0.001)\end{array}$ \\
\hline inv & $\begin{array}{c}2.07 \\
(0.166)\end{array}$ & $\begin{array}{c}8.11 \\
(0.178)\end{array}$ & $\begin{array}{c}2.45 \\
(0.173)\end{array}$ & $\begin{array}{c}-9.37 \\
(0.241)\end{array}$ & $\begin{array}{l}-8.08 \\
(0.213)\end{array}$ & $\begin{array}{c}-3.4 \\
(0.246)\end{array}$ \\
\hline$x$ & $\begin{array}{l}2.51^{* * *} \\
(0.897) \\
\end{array}$ & $\begin{array}{l}2.16^{* * *} \\
(0.705)\end{array}$ & $\begin{array}{l}2.64^{* * *} \\
(0.108)\end{array}$ & $\begin{array}{l}1.73^{* * *} \\
(0.634) \\
\end{array}$ & $\begin{array}{c}4.56^{*} \\
(0.479) \\
\end{array}$ & $\begin{array}{c}3.51^{*} \\
(0.538) \\
\end{array}$ \\
\hline$m$ & $\begin{array}{l}-3.20^{* * *} \\
(0.112)\end{array}$ & $\begin{array}{l}-3.04^{* * * *} \\
(0.102)\end{array}$ & $\begin{array}{l}-3.95^{* * *} \\
(0.104)\end{array}$ & $\begin{array}{l}-1.70^{*} \\
(0.151)\end{array}$ & $\begin{array}{l}-2.61^{*} \\
(0.163)\end{array}$ & $\begin{array}{l}-2.69^{*} \\
(0.215)\end{array}$ \\
\hline$d e v$ & $\begin{array}{l}-0.069 \\
(0.388)\end{array}$ & $\begin{array}{l}-0.079 \\
(0.349)\end{array}$ & $\begin{array}{l}-0.013 \\
(0.401)\end{array}$ & $\begin{array}{l}-0.013 \\
(0.339)\end{array}$ & $\begin{array}{l}-0.084 \\
(0.263)\end{array}$ & $\begin{array}{l}-0.216 \\
(0.215)\end{array}$ \\
\hline cst & $\begin{array}{c}6.085^{* * * *} \\
(1.37)\end{array}$ & $\begin{array}{r}8.191^{* * *} \\
(0.511)\end{array}$ & $\begin{array}{l}9.269^{* * * *} \\
(0.428)\end{array}$ & $\begin{array}{l}9.672^{* * * *} \\
(0.429)\end{array}$ & $\begin{array}{c}10.665^{* * * *} \\
(0.61)\end{array}$ & $\begin{array}{c}11.799^{* * *} \\
(0.808)\end{array}$ \\
\hline Adjusted R2 & 0.46 & 0.56 & 0.44 & 0.6 & 0.75 & 0.84 \\
\hline Obs. & 175 & 175 & 175 & 175 & 175 & 175 \\
\hline
\end{tabular}

Table 4: Dynamic effect on GDP per capita of gender inequality in education completion based on population within specific age brackets (GMM system estimator)

\begin{tabular}{|c|c|c|c|c|c|c|}
\hline Dependent variables & $\begin{array}{l}\text { (16) } \\
\text { GDP per capita }\end{array}$ & $\begin{array}{l}\text { (17) } \\
G D P \text { per capita }\end{array}$ & $\begin{array}{l}\text { (18) } \\
\text { GDP per capita }\end{array}$ & $\begin{array}{l}\text { (19) } \\
\text { GDP per capita }\end{array}$ & $\begin{array}{l}\text { (20) } \\
\text { GDP per capita }\end{array}$ & $\begin{array}{c}\text { (21) } \\
G D P \text { per capito }\end{array}$ \\
\hline dgp per capita $(-1)$ & $\begin{array}{c}0.752^{* * * *} \\
(0.049)\end{array}$ & $\begin{array}{c}0.787^{* * * *} \\
(0.055)\end{array}$ & $\begin{array}{c}0.783^{* * * *} \\
(0.043)\end{array}$ & $\begin{array}{c}0.772^{* * *} \\
(0.062)\end{array}$ & $\begin{array}{c}0.797^{* * *} \\
(0.064)\end{array}$ & $\begin{array}{c}0.781^{* * * *} \\
(0.057)\end{array}$ \\
\hline comp_prim_15-24(-2) & $\begin{array}{l}0.095^{*} \\
(0.053)\end{array}$ & --- & ---- & ---- & --- & --- \\
\hline comp_lowsec_15-24 & --- & $\begin{array}{c}0.847^{* * *} \\
(0.263)\end{array}$ & ---- & ---- & --- & --- \\
\hline comp_lowsec_15-24(-1) & --- & $\begin{array}{l}-1.507 \\
(0.407)\end{array}$ & ---- & ---- & ---- & --- \\
\hline comp_lowsec_15-24(-2) & - & $\begin{array}{c}0.723^{* * * *} \\
(0.193)\end{array}$ & --- & --- & - & --- \\
\hline comp_upsec_20-29(-1) & --- & ---- & $\begin{array}{c}0.401^{* * *} \\
(0.079)\end{array}$ & --- & ---- & -- \\
\hline comp_upsec_20-29(-2) & - & - & $\begin{array}{c}-1 \\
(0.224)\end{array}$ & --- & ----- & -- \\
\hline
\end{tabular}




\begin{tabular}{|c|c|c|c|c|c|c|}
\hline comp_upsec_20-29(-3) & --- & --- & $\begin{array}{c}0.656^{* * *} \\
(0.149)\end{array}$ & --- & --- & --- \\
\hline comp_higher_25-29_2years & --- & --- & - & $\begin{array}{c}0.188 \\
(0.211)\end{array}$ & - & - \\
\hline comp_higher_25-29_2years(-1) & --- & --- & --- & $\begin{array}{l}-0.437 \\
(0.356)\end{array}$ & --- & - \\
\hline comp_higher_25-29_2years(-2) & - & ---- & ---- & $\begin{array}{c}0.336^{* * *} \\
(0.137)\end{array}$ & --- & ---- \\
\hline comp_higher_25-29_4years & - & --- & --- & -- & $\begin{array}{c}0.389^{* * * *} \\
(0.132)\end{array}$ & ---- \\
\hline comp_higher_25-29_4years(-1) & - & --- & -- & 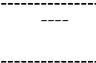 & $\begin{array}{c}-0.348 \\
(0.095)\end{array}$ & - \\
\hline comp_higher_30-34_4years & --- & ---- & ---- & ---- & --- & $\begin{array}{l}0.151^{* *} \\
(0.078)\end{array}$ \\
\hline comp_higher_30-34_4years(-1) & --- & --- & -- & --- & -- & $\begin{array}{l}-0.069 \\
(0.087)\end{array}$ \\
\hline mortality & $\begin{array}{l}-0.002 \\
(0.001)\end{array}$ & $\begin{array}{l}-0.002 \\
(0.001)\end{array}$ & $\begin{array}{l}-0.001 \\
(0.001)\end{array}$ & $\begin{array}{l}-0.002 \\
(0.001)\end{array}$ & $\begin{array}{c}-0.003^{* *} \\
(0.001)\end{array}$ & $\begin{array}{c}-0.003^{* * *} \\
(0.001)\end{array}$ \\
\hline lot*ouv & $\begin{array}{l}0.001^{* * *} \\
(0.001)\end{array}$ & $\begin{array}{c}0.001^{* * *} \\
(0.001)\end{array}$ & $\begin{array}{l}0.001^{*} \\
(0.001)\end{array}$ & $\begin{array}{l}0.001^{*} \\
(0.001)\end{array}$ & $\begin{array}{l}0.001^{*} \\
(0.001)\end{array}$ & $\begin{array}{c}0.001 \\
(0.001)\end{array}$ \\
\hline inv & $\begin{array}{c}-1.19 \\
(0.359)\end{array}$ & $\begin{array}{c}1.29 \\
(0.329)\end{array}$ & $\begin{array}{c}1.83 \\
(0.326)\end{array}$ & $\begin{array}{c}-1.71 \\
(0.376)\end{array}$ & $\begin{array}{c}-8.62 \\
(0.375)\end{array}$ & $\begin{array}{c}-1.41 \\
(0.482)\end{array}$ \\
\hline$x$ & $\begin{array}{l}4.39^{* * *} \\
(0.986)\end{array}$ & $\begin{array}{l}4.17^{* * *} \\
(0.115)\end{array}$ & $\begin{array}{l}5.13^{* * * *} \\
(0.102)\end{array}$ & $\begin{array}{l}4.99^{* * * *} \\
(0.108)\end{array}$ & $\begin{array}{l}3.62^{* * *} \\
(0.911)\end{array}$ & $\begin{array}{l}3.14^{* * *} \\
(0.697)\end{array}$ \\
\hline$m$ & $\begin{array}{c}-2.47 \\
(0.174)\end{array}$ & $\begin{array}{c}-4.08^{* * *} \\
(0.163)\end{array}$ & $\begin{array}{c}-3.71^{* * *} \\
(0.14)\end{array}$ & $\begin{array}{c}-3.58^{* * *} \\
(0.195)\end{array}$ & $\begin{array}{c}-2.4 \\
(0.219)\end{array}$ & $\begin{array}{l}-1.08 \\
(0.284)\end{array}$ \\
\hline dev & $\begin{array}{c}-.0245^{* * *} \\
(0.044)\end{array}$ & $\begin{array}{c}-0.244^{* * *} \\
(0.048)\end{array}$ & $\begin{array}{c}-0.217^{* * *} \\
(0.047)\end{array}$ & $\begin{array}{c}-0.223^{* * *} \\
(0.052)\end{array}$ & $\begin{array}{c}-0.217^{* * *} \\
(0.054)\end{array}$ & $\begin{array}{c}-0.231^{* * * *} \\
(0.052)\end{array}$ \\
\hline$c s t$ & $\begin{array}{c}1.919^{* * *} \\
(0.224)\end{array}$ & $\begin{array}{c}1.742^{* * *} \\
(0.299)\end{array}$ & $\begin{array}{c}1.736^{* * * *} \\
(0.233)\end{array}$ & $\begin{array}{c}1.988^{* * * *} \\
(0.446)\end{array}$ & $\begin{array}{c}1.752^{* * *} \\
(0.509)\end{array}$ & $\begin{array}{c}2.131^{* * *} \\
(0.665)\end{array}$ \\
\hline Obs. & 165 & 165 & 160 & 165 & 170 & 170 \\
\hline
\end{tabular}

According to Table 1, there are strong inequalities between men and women in terms of education completion. In fact, whatever age group is chosen, women represent less than $50 \%$ of total population that has completed the chosen level of study. In this context, an increase of the percentage of women who complete school means that there is a decrease of gender inequalities in education in the age group. Starting from this premise, we observe that an increase of the percentage of women's education completion has a positive and significant effect on the level of GDP per capita. This result is valid for both static and dynamic estimates. Thus, like the estimates using the GPI, a decrease of gender inequalities in education completion according to age groups has a beneficial effect on the GDP per capita in the CEMAC countries. As these results, we deduce that CEMAC countries need to implement policies that reduce gender inequalities in education for sustainable economic growth.

\section{Conclusion}

The contributions of the study are theoretical and empirical. Theoretically, drawing on the model of Solow (1957), it can be seen that CEMAC GDP with gender equality in education is superior to CEMAC GDP with gender inequality. This theoretical result is empirically verified. Indeed, the results obtained show that an increase of gender equality index at the primary-secondary and tertiary levels increases GDP per capita. Like the estimates using the GPI, a decrease of gender inequalities in education completion according to age groups has a beneficial effect on the GDP in the CEMAC countries. In addition, the study establishes an indirect negative impact of political instability, oil shocks and adolescent fertility on per capita GDP. Finally, the study shows that the decreases of gender inequalities in the labor market, FDI and public spending have a beneficial indirect effect on GDP (results available on request).

\section{References}

Agénor, P.R. and O. Canuto (2015) «Gender equality and economic growth in Brazil: A long-run analysis », Journal of Macroeconomics 43 (2015) 155-172. 
Agénor, P.R., O. Canuto and L.P. da Silva (2010) «On Gender and Growth: The Role of Intergenerational Health Externalities and Women's Occupational Constraints "), Policy Research Working Paper 5492.

Agénor, P., J. Mares and P. Sorsa (2015) "Gender Equality and Economic Growth in India: A Quantitative Framework", OECD Economics Department Working Papers, No. 1263, OECD Publishing, Paris.

Baliamoune-Lutz and McGillivray (2009) "Does Gender Inequality Reduce Growth in Sub Saharan African and Arab Countries? », African Development Review, Vol. 21, No. 2, pp. 224-242, 2009.

Bint-e-Ajaz, M. and Ellahi, N. (2012) "Public-Private Investment and Economic Growth in Pakistan: An Empirical Analysis. » The Pakistan Development Review, Vol. 51, No. 4.

Blundell, R. and S. Bond (1998) «Initial conditions and moment restrictions in dynamic panel data models. » Journal of Econometrics, 87, 115-143.

Brummet, Q. (2008) "The Effect of Gender Inequality on Growth: A Cross-Country Empirical Study." The Park Place Economist vol. XVI.

Dollar, D. and R. Gatti (1999) "Gender Inequality, Income and Growth: Are Good Times good for Women?" Mimeographed. Washington CD: The World Bank.

Eicher T. S., S. F. Schubert and S. J. Turnovsky (2008) "Dynamic effects of terms of trade shocks: The impact on debt and growth", Journal of International Money and Finance, 27, 876-896

Hill, A., and E. M. King (1995) "Women's Education and Economic Well-being." Feminist Economics 1(2): 1-26.

International Monetary Funds (IMF) (2015) "Central African Economic and Monetary Community (CEMAC)", IMF Country Report No. 15/308.

Kalemli-Ozcan. S. (2002) "Does the Mortality Decline Promote Economic Growth." Journal of Economic Growth, 7, 411-439.

Klasen, S., and F. Lamanna (2009) "The Impact of Gender Inequality in Education and Employment on Economic Growth: New Evidence For a Panel of Countries." Feminist Economics 15(3): 91-132.

Lagerlöf, N. 1999. Gender Inequality, Fertility, and Growth. Mimeographed, Department of Economics, University of Sydney.

Lagerlof, N. P. 2003. "Gender equality and logn run growth." Journal of Economic Growth 8: 403-426.

Lehmijoki, U. and T. Palokangas. 2011. "The Long-Run Effects of Mortality Decline in Developing Countries.” IZA Discussion Paper No. 5422.

Licumba, E. A., J. Dzator, and J. X. Zhang. 2015. "Gender Equality in Education and Economic Growth in selected Southern African Countries." Proceedings of the Australasian Conference on Business and Social Sciences 2015, Sydney.

Nakamura A. and M. Nakamura (1981), « On the Relationships among Several Specification Error Tests Presented by Durbin, Wu and Hausman », Econometrica, 49 : 1583-1588.

Osundina K. C. and A. J. Osundina. 2014. «Effectiveness of Naira Devaluation on Economic Growth in Nigeria. » International Journal of Science and Research (IJSR), Vol. 5 Iss. 3.

Qureshi, S. A., M., Khan, A., Rafique, G., Khan, M. S., Wahid, and A. Nazli. 2011. "Gender differential in education and its impact on economic growth: Pakistan study (1965-2007), a generalized method of moment approach." Interdisciplinary Journal of Contemporary Research in Business 3(2): 1310-1317.

Roodman, D. (2009) "A note on the theme of too many instruments" Oxford Bulletin of Economics and statistics 71, no. 1: 135-158.

Seguino, S., and M. Were. 2013. "Gender, development, and economic growth in sub-Saharan Africa.” Journal of African Economics 23(1): 18-61. 
Sen, A. 1999. Development as Freedom. New York: Knopf.

Shahzad, I. and M. Y. Afzal. 2013. "Impact of currency devaluation on the exports: a comparative study on Pakistan, Bangladesh and India." A research Journal of Commerce, Economics and Social Sciences, vol. 7, Iss. 1.

Solow, R.M.1957. Technical Change and the Aggregate Production Function. The Review of Economics and Statistics, Vol. 39, No. 3, pp. 312-320.

Yovo, K. 2017. "Public Expenditures, Private Investment and Economic Growth in Togo" Theoretical Economics Letters, 7, 193-209. 